\title{
Rancang Bangun Monitoring Kinerja Solar Cell Menggunakan Labview
}

\author{
Muhammad Ruswandi Djalal \\ Politeknik Negeri Ujung Pandang \\ Jalan Perintis Kemerdekaan KM.10, Makassar \\ wandi@poliupg.ac.id
}

\author{
Nasrun \\ Politeknik Negeri Ujung Pandang \\ Jalan Perintis Kemerdekaan KM.10, Makassar \\ nasrun@poliupg.ac.id
}

\begin{abstract}
Monitoring of solar cell output parameters is needed to assess the performance of a solar cell at changes in the intensity of sunlight. Monitoring using software aims to make monitoring done in real time, in addition it can also function as a data logger, which at any time can be used for system analysis purposes. Thus, a monitoring system is needed that can measure, acquire, display and store measurement data or monitoring solar cell performance. Monitoring data is also expected to be accessed by relevant parties more easily and quickly. In this study, monitoring is useful to provide measurement results that have the smallest possible error rate, easily accessible in real time and able to display graphs of measurement results. The software used for monitoring systems in this study is Labview software that is able to show high performance in communicating with multiple devices simultaneously and high ability to display multiple variable behaviors at a time. In this study, monitoring the performance of solar cells that will be displayed on Labview is voltage and current.
\end{abstract}

Keywords: Solar Cell, Monitoring, Parameters, Error, Labview.

\section{PENDAHULUAN}

Dewasa ini ilmu pengetahuan dan teknologi mengalami perkembangan yang sangat pesat. Beberapa diantaranya adalah di bidang komputer dan sistem pengiriman data. Dua hal tersebut merupakan suatu rangkaian padu yang tidak dapat dipisahkan. Dampak positif yang dapat dirasakan akibat perkembangan teknologi tersebut salah satunya adalah membantu pekerjaan manusia, dimana dahulu dilakukan secara manual, sekarang dilakukan secara otomatis sehingga dapat meningkatkan efisiensi kerja. Sebagai contoh dalam monitoring daya listrik solar cell memerlukan bantuan komputer.

Pemantauan terhadap parameter keluaran solar cell sangat diperlukan untuk menilai kinerja sebuah solar cell pada perubahan intensitas cahaya matahari. Pemantauan menggunakan software bertujuan agar pemantauan bersifat real time sehingga dalam pemantauan tidak memerlukan cara manual dengan menggunakan alat ukur yang tidak bersifat real time. Maka, diperlukan sistem monitoring yang dapat mengukur, mengakuisisi, menampilkan dan menyimpan data pengukuran atau pemantauan kinerja solar cell [1].

Untuk memenuhi kebutuhan tersebut, perangkat dan sistem monitoring dirancang agar memudahkan dalam kegiatan pemantauan unit pada lokasi yang terpasang. Data pemantauan juga diharapkan dapat diakses oleh pihak terkait dengan lebih mudah dan cepat. Pada penelitian ini, monitoring berguna untuk memberikan hasil pengukuran yang memiliki tingkat ralat atau error sekecil mungkin, mudah diakses secara real time dan mampu menampilkan grafik hasil pengukuran. Software yang digunakan untuk sistem monitoring pada penelitian ini adalah software Labview yang mampu menujukkan kinerja tinggi dalam berkomunikasi dengan beberapa perangkat secara bersamaan dan kemampuan yang tinggi dalam menampilkan beberapa perilaku variabel dalam satu waktu . Pada penelitian ini, monitoring kinerja solar cell yang akan ditampilkan pada Labview adalah arus, tegangan, dan temperatur.

Penelitian terkait sistem monitoring solar cell telah banyak dilakukan, diantaranya, pada penelitian [2, 3], sistem pemantauan kinerja solar cell yang dirancang dilengkapi dengan sensor pengukur arus dan tegangan dengan menggunakan Excel. Pada penelitian [4], pembuatan sistem pemantauan keluaran solar cell yang terpasang berupa tegangan, arus, dan daya. Pada penelitian [5], monitoring system kinerja solar cell untuk parameter arus, tegangan dan daya pada komponen batterai. Pada penelitian [6], sistem monitoring solar cell ini dapat mencatat arus, tegangan, suhu serta kelembaban secara real time, yang dihasilkan dari hasil kinerja solar cell dan kemudian merekamnya dalam bentuk TXT file. Pada penelitian [1], monitoring data arus dan tegangan ditampilkan pada layar yang terdapat di box panel secara real time. Pada penelitian [7], Informasi mengenai tegangan dan arus dari solar cell yang dikumpulkan pada kondisi real time dapat diperoleh langsung melalui dokumen Excel yang datanya didapatkan dari database. Pada penelitian [8], Monitoring tegangan dan beban pada solar cell ini berbasis mikrokontroler. Pada penelitian [9] membahas tentang monitoring kinerja solar cell berbasis Simulink.

Berdasarkan penelitian yang sudah ada, penulis membuat penelitian sistem monitoring solar cell secara real time. Penelitian ini menggunakan software Labview untuk menampilkan data monitoring kinerja solar cell seperti, tegangan, arus, daya, debu, suhu dan kelembapan. Data hasil 


\section{Rancang Bangun Monitoring Kinerja Solar Cell Menggunakan Labview}

monitoring tersebut dapat tersimpan sebagai data logger untuk keperluan analisa kinerja solar cell.

\section{METODE PENELITIAN}

\section{A. Desain Hardware}

Desain hardware mencakup sensor (Arus, Tegangan, Debu, Suhu dan Kelembapan), rangkaian penkondisian sinyal (penyearah), perangkat interface arduino uno, sebuah laptop dan beban.

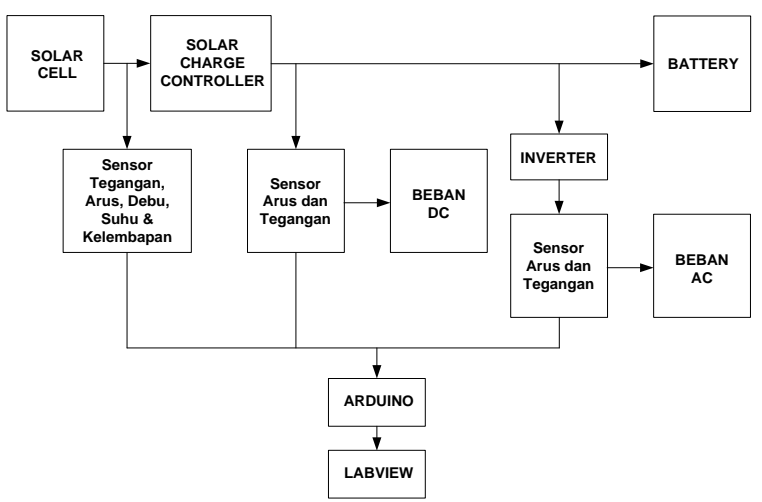

Gambar 1. Desain Hardware

\section{B. DESAIN SOFTWARE}

Desain software mencakup desain Interfacing Labview-Arduino menggunakan software Labview 2017. Untuk keperluan interfacing Labview dan Modul Arduino dibutuhkan driver Ni-Visa.

Tahap pertama adalah melakukan pemodelan system pada software Labview, berikut pemodelan system secara keseluruhan untuk monitoring kinerja solar cell. Dalam penelitian ini digunakan beban lampu DC 12 Volt 30 Watt sebanyak 2 buah.

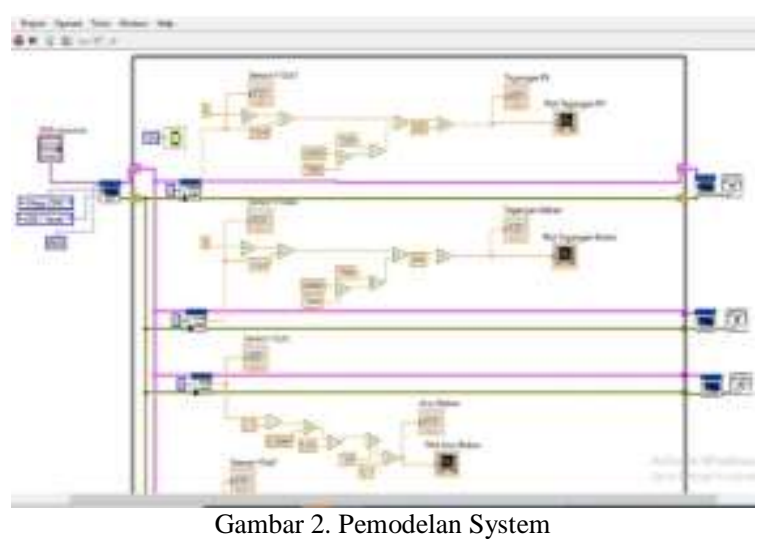

Pemodelan system yang dibuat antara lain, sistem monitoring untuk solar cell yaitu monitoring tegangan, arus, serta temperature solar cell. Kemudian sistem monitoring beban DC yang terdiri dari sistem monitoring tegangan dan arus beban.

\section{PERENCANAAN SOLAR CELL}

Langkah-langkah perencanaan teknologi PV adalah sebagai berikut:
1. Mencari total beban pemakaian per hari Rumus yang digunakan adalah sebagai berikut: Beban Pemakaian $(\mathrm{Wh})=$ Daya $\mathrm{x}$ Lama Pemakaian

Di mana kebutuhan daya:

- 2 Beban Lampu Led 12 Volt @2 Watt x 12 Jam sehari $=48 \mathrm{Wh}$

- 1 Beban Lampu Led 12 Volt @12 Watt x 12 Jam sehari $=144 \mathrm{Wh}$

- 1 Beban Pompa Air 12 Volt @60 Watt x 5 Jam sehari $=300 \mathrm{Wh}$

Maka, total pemakaian daya $=492 \mathrm{Wh}$

2. Menentukan ukuran kapasitas modul surya yang sesuai dengan beban pemakaian. Rumus yang digunakan adalah:

Kapasitas Modul Surya $=\frac{\text { Total Beban Pemakaian Harian }}{\text { Insolasi Surya Harian }}$

Maka, jumlah solar cell yang dibutuhkan, jika satu panel kita hitung $100 \mathrm{~W}$, adalah:

Kapasitas modul surya $=(492 / 100 \times 5)=98,4$ $=1$,

Di mana, Insolasi surya harian adalah ketersediaan energi surya rata-rata di Indonesia sekitar 4,8 kWh/m2.

3. Menentukan kapasitas baterai/aki. Rumus yang digunakan adalah:

Kapasitas Baterai $(A h)=\frac{\text { Total Kebutuhan Energi Harian }}{\text { Tegangan Sistem }}$

Jumlah kebutuhan baterai 12 Volt dengan masing-masing $100 \mathrm{Ah}$ :

Kebutuhan baterai minimum (baterai hanya digunakan $50 \%$ untuk pemenuhan kebutuhan listrik), dengan demikian kebutuhan daya kita kalikan 2 x lipat:

Kapasitas Baterai $=492 \times 2=984 \mathrm{Wh}=$ 984/12 Volt $/ 100$ Amp $=0,82=1$ Baterai 100 Ah.

\section{HASIL \& PEMBAHASAN}

Pada hasil penelitian perangkat hardware mencakup prototype monitoring kinerja solar cell, software mencakup desain pemodelan software Labview. Berikut hasil real time monitoring kinerja solar cell dengan menggunakan Labview.

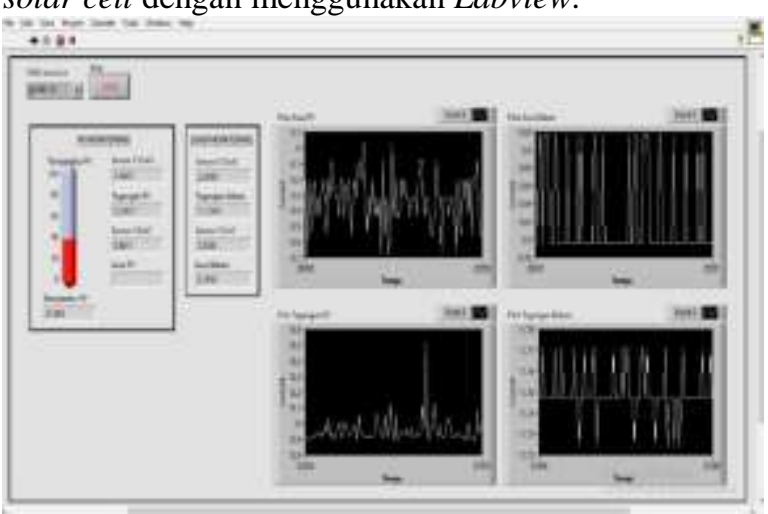

Gambar 3. Real Time Monitoring Kinerja Solar Cell 


\section{Rancang Bangun Monitoring Kinerja Solar Cell Menggunakan Labview}

Dari hasil pengujian monitoring kinerja solar cell, didapatkan suatu sistem yang dapat memonitoring kinerja solar cell secara real time dengan menggunakan software Labview. Pengembangan penelitian ini adalah mengkombinasikan algoritma cerdas untuk mengidentifikasi pemakaian beban pada solar cell [10].

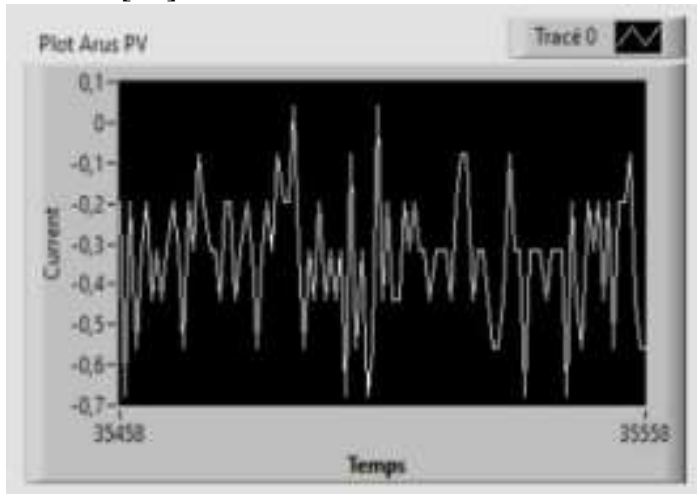

Gambar 4. Real Time Monitoring Arus Solar Cell

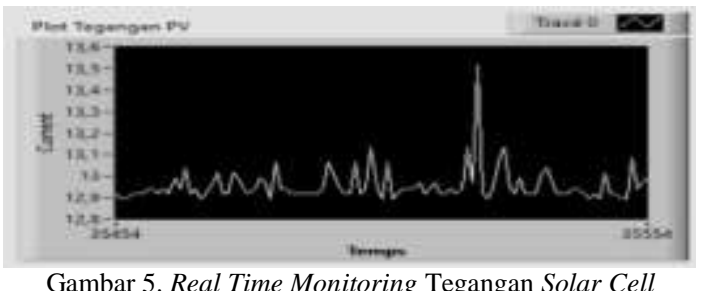

Gambar 5. Real Time Monitoring Tegangan Solar Cell

Gambar 4 menunjukkan hasil monitoring kinerja solar cell untuk parameter arus dan tegangan, pada kondisi ini pengisian baterai sudah penuh, sehingga tidak ada arus yang terbaca. Adanya fluktuasi pada grafik disebabkan oleh sangat sensitifnya sensor arus ACS 758 yang digunakan. Sedangkan gambar 5 menunjukkan grafik pengukuran tegangan solar cell.

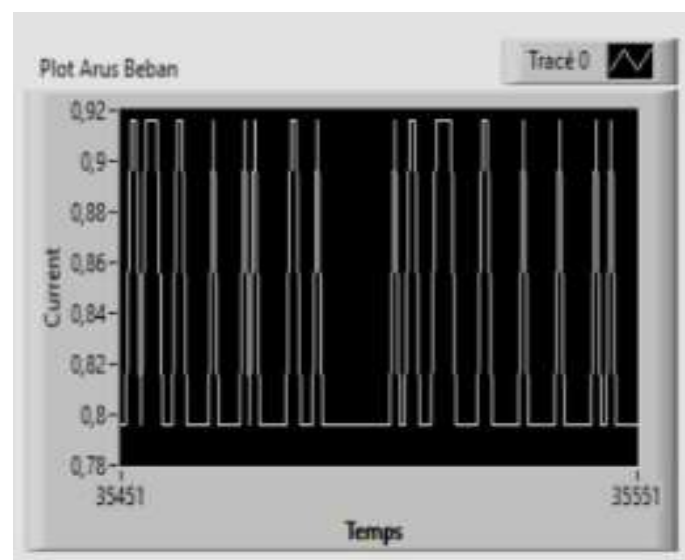

Gambar 6. Real Time Monitoring Arus Beban Solar Cell

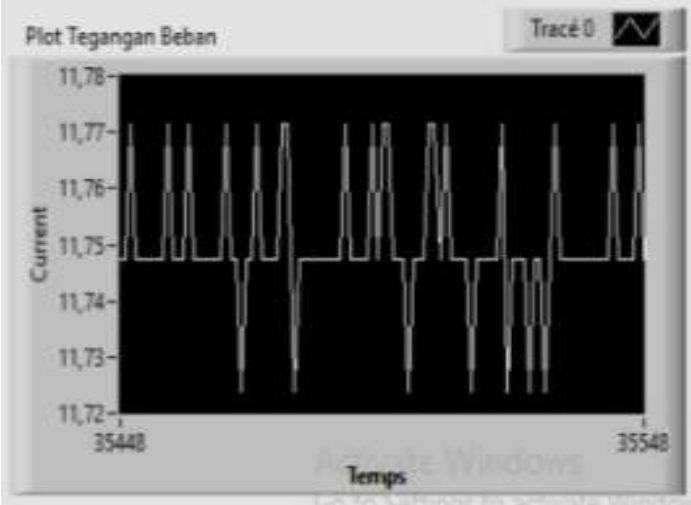

Gambar 7. Real Time Monitoring Tegangan Beban Solar Cell

Gambar 6 menunjukkan hasil monitoring beban solar cell untuk parameter arus dan tegangan, pada kondisi ini beban lampu 12 volt 30 watt sedang bekerja, dengan konsumsi arus sebesar 0,9 Watt. Adanya fluktuasi pada grafik disebabkan oleh sangat sensitifnya sensor arus ACS 758 yang digunakan. Sedangkan gambar 7 menunjukkan grafik pengukuran tegangan pada terminal beban atau tegangan baterai. Gambar 8, 9, dan 10 menunjukkan perangkat pengujian yang digunakan dalam penelitian ini.

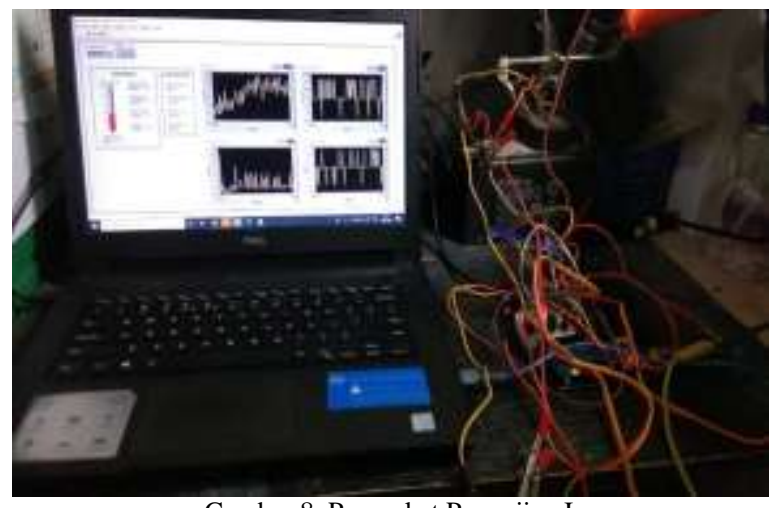

Gambar 8. Perangkat Pengujian I

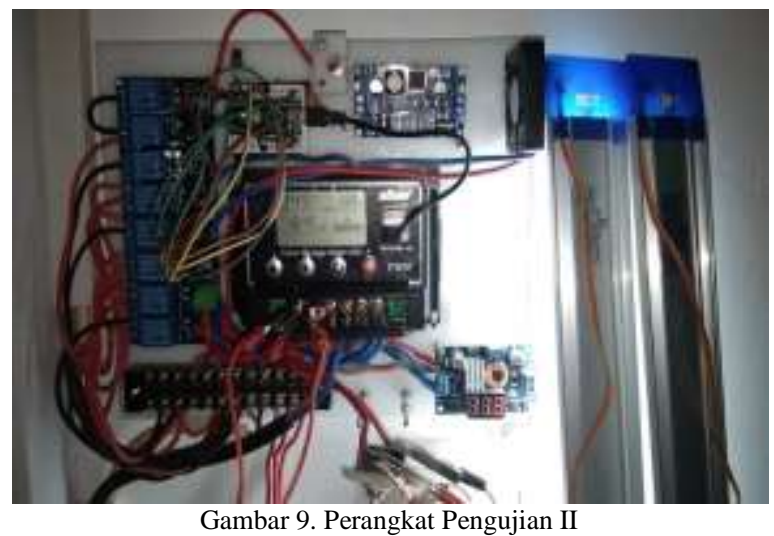




\section{Rancang Bangun Monitoring Kinerja Solar Cell Menggunakan Labview}

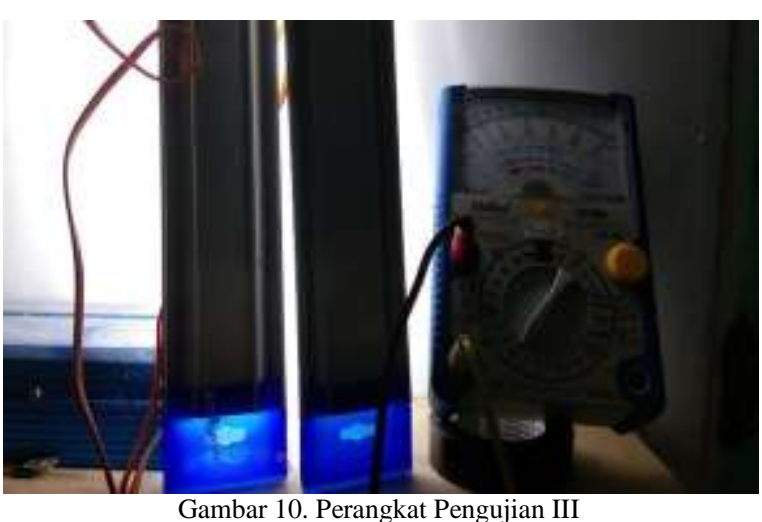

\section{KESIMPULAN}

Penelitian ini bertujuan memberikan suatu teknik baru pemantauan secara langsung dan real time untuk arus, dan tegangan solar cell. Untuk memenuhi keperluan tersebut, sistem monitoring performa solar cell yang dirancang dilengkapi dengan sensor pengukur arus dan tegangan. Hasil dari sistem monitoring ini adalah pengukuran dari setiap sensor dapat diproses secara langsung dan ditampilkan dalam bentuk grafik pada kondisi real time serta dapat disimpan sebagai data log. File ini dapat dikonversi menjadi file Excel dan Notepad.

\section{DAFTAR PUSTAKA}

[1] Syahid, Sugijono, A. Santoso, A.H. Riyadi. "Rancang Bangun Monitoring Pengisian Baterai pada Solar Cell di Laboratorium Timur Teknik Listrik Politeknik Negeri Semarang," Seminar Nasional Vokasi Indonesia, Volume 1, pp.156-161, 2018.

[2] M. Vyas, K. Chudasama, M. Bhatt, and B. Gohil, "Real time data monitoring of PV solar cell using LabVIEW," International Journal of Current Engineering and Technology, Vol.6, No.6, 2016.

[3] Syarif, Irwan. "Pemanfaatan Hibrid Pembangkit Listrik Tenaga Surya dan Angin Di Pulau Bunaken." Patria Artha Technological Journal 1.1 (2017): 21-36.

[4] Usman, U., \& Sirad, M. A. H. (2021, May). Characteristic Testing Of Simulation-Based Photovoltaic Models. In IOP Conference Series: Materials Science and Engineering (Vol. 1125, No. 1, p. 012064). IOP Publishing.

[5] R. P. J. J. E. Pratama, "Perancangan sistem monitoring battery solar cell pada lampu PJU berbasis web,"Jurnal ELTEK, vol. 12, no. 1, pp. 5063, 2017.

[6] H. Suryawinata, D. Purwanti, and S. J. J. T. E. Sunardiyo, "Sistem monitoring pada panel surya menggunakan data logger berbasis ATMega 328 dan Real Time Clock DS1307," Jurnal Teknik Elektro, vol. 9, no. 1, pp. 30-36, 2017.

[7] R. R. A. Siregar, N. Wardana, and L. J. J. J. I. T. E. Luqman, "Sistem Monitoring Kinerja Panel Listrik Tenaga Surya Menggunakan Arduino Uno," JETRI: Jurnal Ilmiah Teknik Elektro, vol. 14, no. 2, pp. 81100, 2017.

[8] T. A. PRIATAMA, "Rancang Bangun Sistem Monitoring Solar Cell Menggunakan Mikrokontroler Arduino Uno R3 dan Data Logger Secara Real
Time," Universitas Muhammadiyah Palembang, 2020.

[9] R. D. Muhammad and T. Tasrif, "Rancang Bangun Monitoring Kinerja Solar Cell Menggunakan Simulink," in Seminar Nasional Hasil Penelitian \& Pengabdian Kepada Masyarakat (SNP2M), 2019, pp. 115-120. 2019.

[10] M. R. Djalal and T. Tasrif, "Pemodelan Identifikasi Pemakaian Beban Solar Panel Berbasis Artificial Neural Network," in Seminar Nasional Hasil Penelitian \& Pengabdian Kepada Masyarakat (SNP2M), pp. 147-152, 2020.
Copyright @2016 PROtek : Jurnal Ilmiah Teknik Elektro cc) (i) (2) lisensi Creative Commons Attribution 4.0 EY NC SA International Licensi 